\title{
Copper Toxicity of Four Different Aquaculture Ponds
}

\author{
Moshod Keke Mustapha*, Joshua Taiwo Agunloye
}

Department of Zoology, Faculty of Life Sciences, University of Ilorin, Ilorin, Nigeria

\section{ABSTRACT}

Copper is a nutritional trace element for fish which could be deficient or toxic. Copper concentrations from four aquaculture ponds were analyzed for 12 weeks using Bicinchoninate method. Alkalinity was measured using colorimetric method with the aid of Hanna Multiparameter Bench Photometer. Temperature and $\mathrm{pH}$ of the ponds was measured in situ using Hanna Portable $\mathrm{pH} / \mathrm{EC} / \mathrm{TDS} / \mathrm{Temp}$ combined waterproof tester. All measurements were done I triplicates. Copper concentrations ranged from 0.01 to $0.10 \mathrm{mg} / \mathrm{L}$, alkalinity ranged from 105 to $245 \mathrm{mg} / \mathrm{L}$. Weeks 1 and 12 recorded the highest and lowest $\mathrm{Cu}^{2+}$ concentrations, while lowest and highest alkalinity were obtained in weeks 1 and 12 respectively in all the ponds. Temperature and $\mathrm{pH}$ ranged from 29.1 to $35.9^{\circ} \mathrm{C}$ and 6.35 to 8.03. The trend of copper concentrations in the ponds was Natural > Earthen > Concrete > Collapsible, with concentration slightly above the normal in the ponds. This could have come from the pipes used in de livering water to the pond, copper alloy nets and mesh used in the ponds, anti-fouling agents, algaecides, water source and fish meal. Effect of elevated copper was seen in the morphology and behavior of Clarias gariepinus which include slimy mucus on the skin, aggressive and uncoordinated swimming with the opercula flared, slow growth, reduced odor perception of food and water bubbles on the ponds. Copper should be regularly bio monitored to determine toxicity in fish.

Keywords: Fish, alkalinity, $\mathrm{pH}$, toxic, management

\section{INTRODUCTION}

Copper $\left(\mathrm{Cu}^{2+}\right)$ is an essential nutritional trace elements required by fish in minute quantity. Wild fish obtain their dietary copper requirements from the water they inhabit and the diet they feed on. The concentrations of copper, its sources and effects in the wild fish habitat and on wild fish population have been by extensively reviewed by [1].

The concentrations of copper in water are dependent on $\mathrm{pH}$, temperature, alkalinity, bicarbonate, sulfide, and organic ligands [2]. Copper is among the most toxic of the heavy metals in freshwater and marine biota [3], and often accumulates and causes irreversible harm to some fish species at concentrations just above levels required for growth and reproduction [4]. The effects of low and high dietary levels of copper in fish have been highlighted by $[5,6]$.

Studies on copper concentrations in aqua cultural

\footnotetext{
*Corresponding author:

Mustapha, M.K

Department of Zoology, Faculty of Life Sciences, University of Ilorin

TEC, University of Ilorin, Ilorin, Nigeria 240003

E-mail: kmoshood@unilorin.edu.ng
}

ponds is essential in aquaculture due to the fact that copper is a trace element required in minute quantity in fish production and anthropogenic contamination of the element in aquaculture tanks and ponds is minimal. Many factors can however introduce copper to aquaculture ponds which could be deleterious to the fish and water quality. These include copper-containing pipes used in delivering water to the pond, copper alloy nets used in harvest, copper alloy mesh used for pen aquaculture, anti-fouling agents containing copper compounds used in controlling organisms that impair the flow of water, algaecides and parasiticides containing copper compounds used in killing alga and parasites, pond water source and fish meal for feeding the fish.

In spite that copper is needed in minute quantity in fish and its introduction to aquaculture water is implausible, its deficiency or toxicity can occur when the

\section{How to cite:}

Mustapha MK, Agunloye JT (2016) Copper toxicity of four

different aquaculture ponds. J. Trop. Life. Science

6 (3): $155-159$. 
concentration in water is too little or in excess of the requirement by fish. This could lead to nutritional problems or toxicity to the fish in culture. The objectives of this paper are to determine the concentrations, source(s), effects and management measures of copper concentration in four different aquaculture ponds used for the culture of African mud catfish Clarias gariepinus. This is the first attempt at determining the toxicity level of copper in different aquaculture tanks used for the culture of an important African fish of culture.

\section{MATERIALS AND METHODS}

\section{Treatments}

Four different aquaculture ponds of the same size and dimension of $4.5 \mathrm{~m} \times 4.5 \mathrm{~m} \times 1 \mathrm{~m},\left(20 \mathrm{~m}^{2} \times 1 \mathrm{~m}\right)$ volume capacity of $20 \mathrm{~m}^{3}(20,000 \mathrm{~L})$ and containing a population of $2000 C$. gariepinus and biomass of $500 \pm$ $50 \mathrm{~g}$ were used for the measurement and effect of copper concentrations. These ponds were collapsible pond, concrete tank, earthen pond and a natural pond. Borehole water is the source of water to the collapsible pond, concrete tank, and earthen pond while the natural pond has its water source from the rains.

Water was collected from the ponds with $50 \mathrm{~mL}$ plastic water bottle in the afternoons at $1 \mathrm{pm}$ weekly for 12 weeks between February and April 2015. Copper concentrations were measured using Bicinchoninate method and alkalinity was measured using colorimetric method with the aid of Hanna Multiparameter Bench Photometer for Laboratories Model HI 83200-02. Temperature and $\mathrm{pH}$ of the ponds were also measured in situ at the same time for the same period using Hanna Portable $\mathrm{pH} / \mathrm{EC} / \mathrm{TDS} / \mathrm{Temp}$ combined waterproof tester Model HI 98129. Triplicates water samples of the ponds were obtained and measured for copper and alkalinity, while $\mathrm{pH}$ and temperature, measurements were also measured in triplicates in situ. Morphological and behavioural changes were observed from the fishes in the different tanks to show the effect of copper toxicity in them.

\section{Statistical analysis}

Stata ver.13 was used to analyze the results. Weekly mean of each parameter was compared using ANOVA at $\mathrm{p}<0.05$ to see the significant differences in each parameter among the four ponds, while correlations between the parameters were also analyzed using data analysis and statistical software Stata Ver13.

\section{RESULTS AND DISCUSSION}

The mean results of copper concentrations, alkalin- ity, $\mathrm{pH}$ and temperature fluctuations in the four ponds are presented in Figures 1, 2, 3, and 4. Copper concentrations ranged from 0.01 to $0.10 \mathrm{mg} / \mathrm{L}$ with highest concentration recorded in natural pond and lowest found in collapsible pond. Alkalinity ranged from 105 to $245 \mathrm{mg} / \mathrm{L}$ with the highest obtained in collapsible pond and lowest recorded in natural pond. Weeks 1 and 12 recorded the highest and lowest $\mathrm{Cu}^{2+}$ concentrations respectively in all ponds, while lowest and highest alkalinity were obtained in weeks 1 and 12 respectively in all the ponds. The trend in the copper concentrations in the ponds is Collapsible pond < Concrete tank $<$ Earthen pond < Natural pond. The bedrock geology of the natural and earthen ponds was found to have a slight high amount of copper. There was a significant difference $(p<0.05)$ in the concentrations of copper among the four ponds and there was positive correlation between the alkalinity and $\mathrm{pH}$, while negative correlations were observed between copper and temperature and $\mathrm{pH}$ in the ponds.

There were temperature and $\mathrm{pH}$ fluctuations in the four ponds, with temperature and $\mathrm{pH}$ ranging from 29.1 to $35.9^{\circ} \mathrm{C}$ and 6.35 to 8.03 respectively, with the highest temperature and $\mathrm{pH}$ recorded in the collapsible pond in week 12 and lowest temperature and $\mathrm{pH}$ found in natural pond in week 1 . There was significant difference $(\mathrm{p}<0.05)$ in temperature and $\mathrm{pH}$ among the four ponds. The temperature and $\mathrm{pH}$ followed seasonal pattern with lowest temperatures and $\mathrm{pH}$ recorded in February corresponding to the end of rainy season and highest temperatures and $\mathrm{pH}$ recorded in April corresponding to the dry season. This scenario is also seen in the alkalinity and copper concentrations in the ponds.

The general pattern of measured factors in the ponds showed that as $\mathrm{pH}$ and temperature increase, alkalinity also increases while copper concentration decreases. The effects of elevated copper concentrations on the fish species $C$. gariepinus were found on the morphological and behavioral changes observed in them especially in natural and earthen ponds. These include slimy mucus on the skin, aggressive and uncoordinated swimming activity and movement, sparkled opercula, slow growth, and gasping.

The source of slight high copper concentrations observed in both natural and earthen ponds were from the bedrock geology of the area which had high amount of copper. Anthropogenic sources into ponds are rules out because the ponds were located in areas where there are no mining and agricultural activities as well as municipal or industrial wastes discharges into 


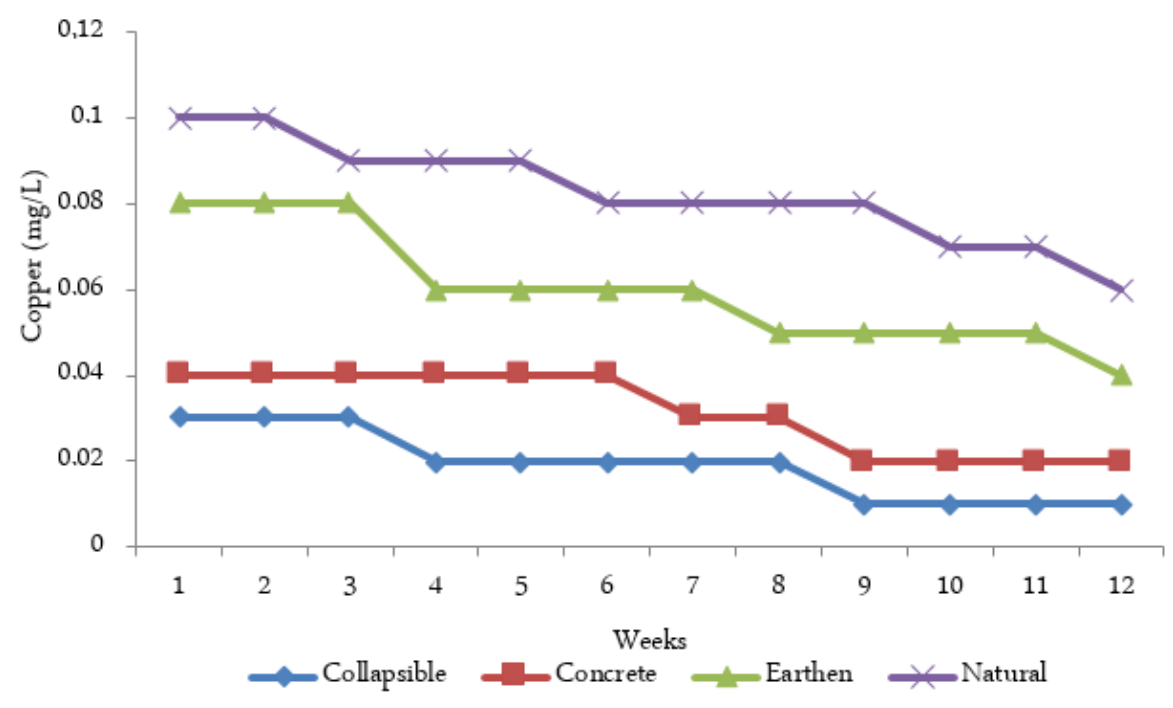

Figure 1. Mean copper concentrations in the ponds

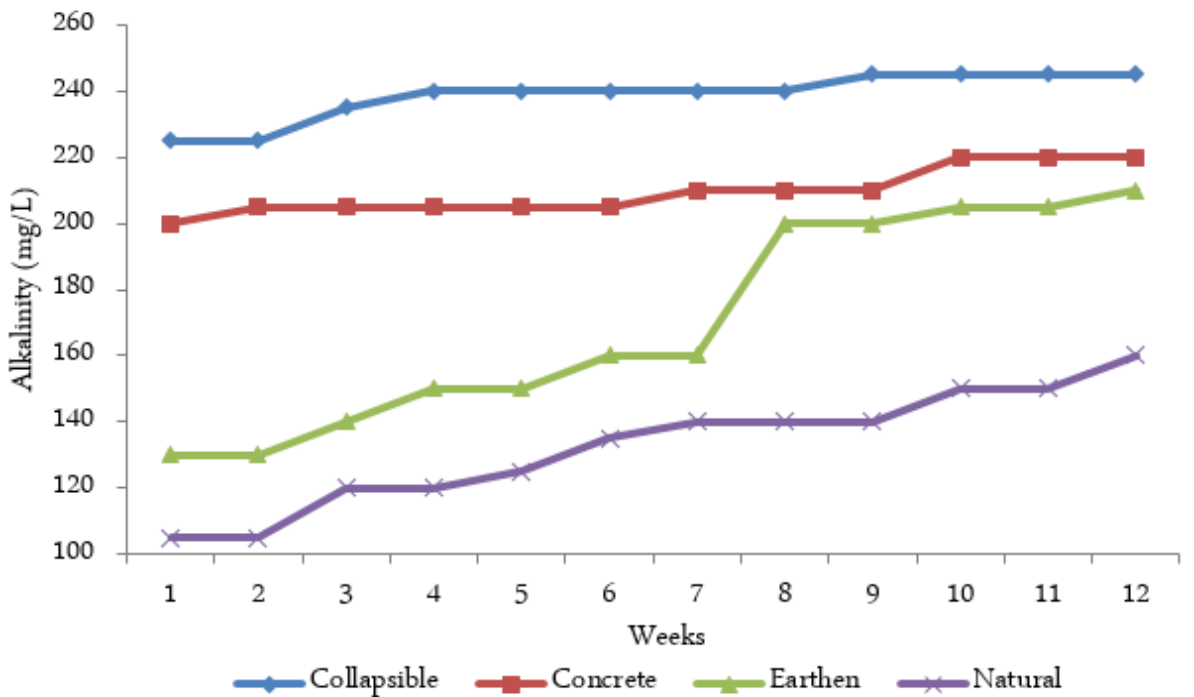

Figure 2. Mean alkalinity in the ponds

the ponds. The high $\mathrm{pH}$ and alkalinity in the collapsible and concrete ponds were responsible for the low copper concentrations recorded in them as compared to earthen and natural ponds, while low $\mathrm{pH}$ and alkalinity as well as the bedrock of the source water in earthen and natural ponds could be responsible for the slight high copper concentrations observed in the two ponds. According to [7] alkalinity, $\mathrm{pH}$ and temperature are responsible for determining copper solubility and toxicity in water, while [8] reported that copper concentration of water is highest when the $\mathrm{pH}$ is low. Similarly, the same scenario was observed for temperature. This explains the negative correlation of copper with $\mathrm{pH}$ and temperature. The interrelationship between copper toxicity with $\mathrm{pH}$ and temperature however needs further investigation as little is known about the interrelationship. The presence of organic and inorganic compounds might be also responsible for the low concentration of copper in these ponds. The absorbance of copper though in minute quantity from the ponds by the fish for binding to -globulin and then transported to the various tissues of the body [9] as well as its use as dietary requirement could also explain the reduction in concentrations of the element in the different ponds over time.

Although, numerous and disparate tolerable, safe and toxicity levels has been established for copper on fish. [10] reported that copper concentration above $0.02 \mathrm{mg} / \mathrm{L}$ is toxic to fish, [11] reported acute toxicity at $0.01-0.02 \mathrm{mg} / \mathrm{L},[1]$ observed that concentration of 


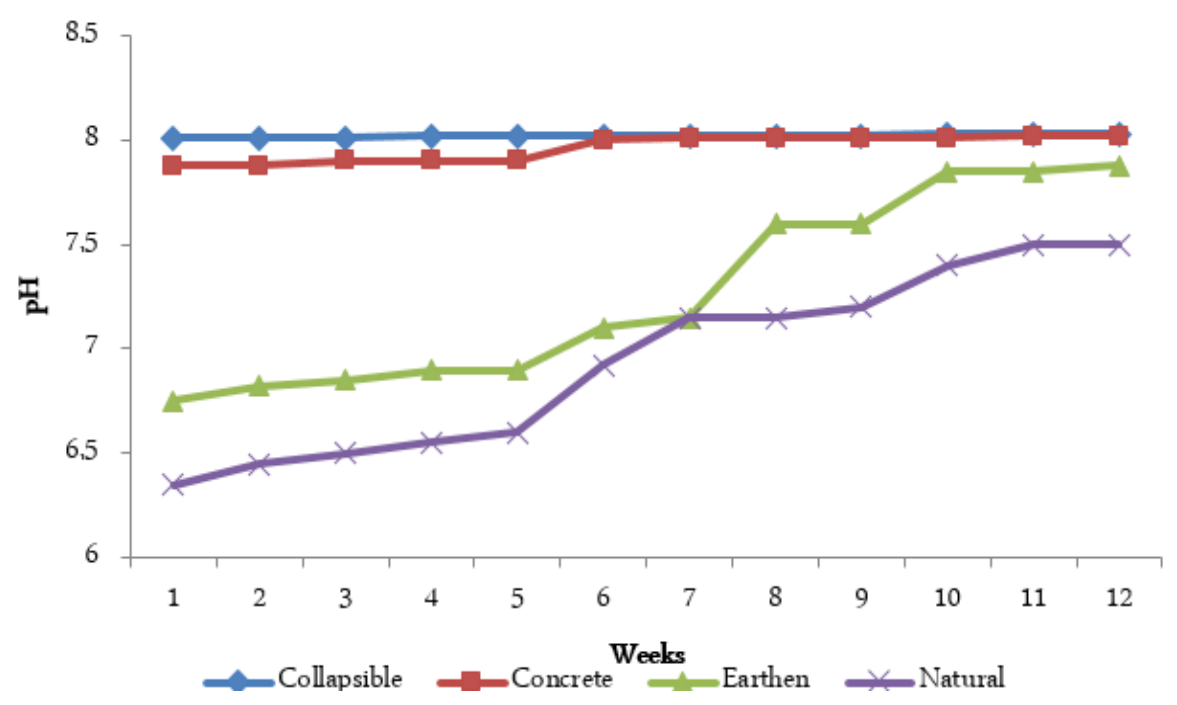

Figure 3. Mean $\mathrm{pH}$ concentrations in the ponds

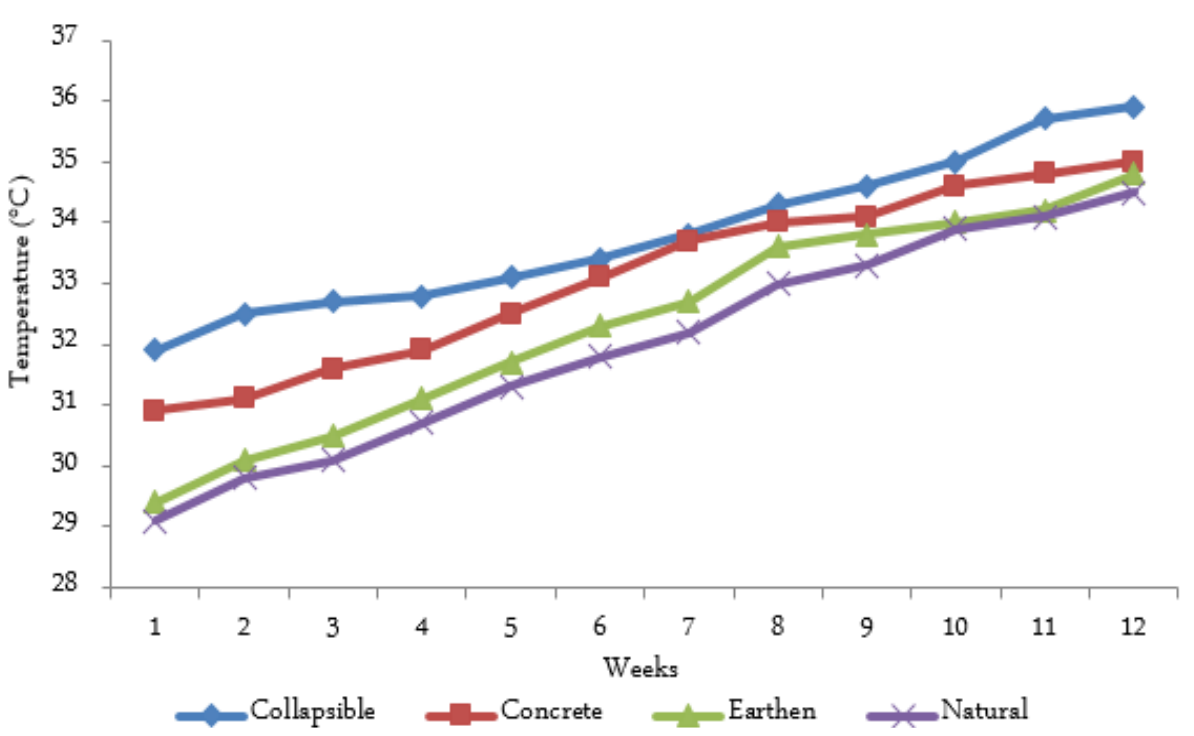

Figure 2. Mean temperature in the ponds

between $0.004-0.01 \mathrm{mg} / \mathrm{L}$ of copper will have sub lethal effect to fish and aquatic food chain, while [12] reported a copper concentration of $0.767-0.991 \mathrm{mg} / \mathrm{L}$ as having lethal concentration with $10-20 \%$ of $C$. gariepinus exposed to the element dead in 96 hours. The levels of copper toxicity in the ponds were slightly elevated above the references. This could have come from the pipes used in delivering water to the pond, copper alloy nets used in harvest, copper alloy mesh used for the ponds, anti-fouling agents containing copper compounds used in controlling organisms that impair the flow of water, algaecides and parasiticides containing copper compounds used in killing alga and parasites, the pond water source and especially fish meal for feeding the fish.
Although, toxicity of copper to fish depends on the species, age of the fish and length of exposure. The fish species C. gariepinus in the different aquaculture ponds showed copper toxicity as seen in the morphological and behavioral changes observed in them. These include, slimy mucus on the skin which could make the fish susceptible to diseases and pathogens, aggressive and uncoordinated swimming activity and movement probably resulting from muscle spasms, with the opercula sparkled, slow growth provably resulting from loss of appetite on account of reduced odor perception of food, water bubbles on the ponds likely occurring as a result of difficulty in breathing. All these effects have also been reported by $[1,13]$, and several other workers on different fish species exposed to different levels 
of copper concentrations.

These effects were as a result of bio availability of the elevated copper in the ponds to the fish which resulted in bio concentration and bioaccumulation of the element over time (i.e. length of exposure) right from the fingerlings stage which was the stage of stocking in the ponds to the adult stage which was the stage at which the measurements were made. Thus, it can be deduced that $C$. gariepinus is sensitive to copper toxicity even at small elevation above the normal background level. This observation has also been reported by $[7,12,14]$ in the fish species.

\section{CONCLUSION}

Copper concentrations in these ponds should be regularly measured especially in the natural and earthen ponds in order to maintain the safe limit and toxicity level of copper concentrations in aqua cultural ponds. Also, bio monitoring of copper concentration in the ponds will help in adjusting the amount of copper to be included in feed since dietary copper is an important route that results in toxicity to fish than water borne copper. These will help in the copper management of the ponds and fish cultured in them.

Fishes stocked in the ponds that showed the effects of elevated copper should be removed and stocked in a new pond where copper concentration of the water is low. This will correct the morphological and behavioral changes seen in the fish species.

\section{ACKNOWLEDGMENT}

\section{REFERENCES}

1. Eisler R (1998) Copper hazards to fish, wildlife, and invertebrates: a synoptic review. U.S.Geological Survey, Biological Resources Division, Biological Science Report.

2. U.S. Environmental Protection Agency (1980) Ambient water quality criteria for copper. U.S. EPA Report. 440/580-036.

3. Betzer SB, Yevich PP (1975) Copper toxicity in Busycon canaliculatum L.. Biol Bull 148: 16-25.

4. Hall WS, Bushong SJ, Hall Jr LW, Lenkevich MS, Pinkney AE (1988) Monitoring dissolved copper concentrations in Chesapeake Bay, U.S.A. Environ. Monit Assess 11: 33-42.

5. Murai T, Andrew JW, Smith G (1981) Effects of dietary copper on channel catfish. Aquaculture 22: 353-7.

6. Gatlin DM, Wilson RP. (1986) Dietary copper requirement of fingerling channel cattish. Aquaculture 54: 27785.

7. Olaifa FE, Olaifa AK, Onwude TE (2004) Lethal and sublethal effects of copper to the African Catfish (Clarias gariepinus) juveniles. Afr J Bio Res 7: 65 -70.

8. Dartman J, Sadhowsky B, Dorsch T, Johansen K (2010) Copper corrosion in drinking water systems - effects of $\mathrm{pH}$ and phosphate dosage. Mater corros 61(3): 189- 98.

9. Aaseth J, Norseth T. (1986). Copper. In: Handbook on the toxicity of metals. Vol. II: Specific metals. 2nd Edition. Friberg L. Nordberg GF, Vouk EB (Eds). Elsevier. New York.

10. Bradl H (2005) Heavy metals in the environment: origin, interaction and remediation. Elsevier/Academic Press. London.

11. National Academy of Sciences (NAS) (1977) Copper. Committee on medical and biological effects of environmental pollutants, National Research Council. National Academy of Sciences. Washington, D.C.

12. van der Merwe M, van Vuren JHJ, du Preez HH (1993) Lethal copper concentration levels for Clarias gariepinus - a preliminary study. Koedoe 36: 77-86.

13. Richey D, Roseboom D (1978) Acute toxicity of copper to some fishes in high alkalinity water. ISWS Circular 131.

14. Oronsaye JAO, Ogunbor EO (1998) Toxicity of Copper to Oreochromis niloticus fingerling in Ikpoba River water. Ind J Ani Sci 68 (9): 1001 - 1003. 